\title{
Effect of different levels of short-term feed intake on folliculogenesis and follicular fluid and plasma concentrations of lactate dehydrogenase, glucose, and hormones in Hu sheep during the luteal phase
}

\author{
Shijia Ying ${ }^{1,2}$, Ziyu Wang ${ }^{1,2}$, Changlong Wang ${ }^{1,2}$, Haitao Nie ${ }^{1,2}$, Dongyang He $\mathrm{H}^{1,2}$, Ruoxin Jia ${ }^{1,2}$, \\ Yongcong $\mathrm{Wu}^{1,2}$, Yongjie Wan ${ }^{1,2}$, Zhengrong Zhou ${ }^{1,2}$, Yibo Yan ${ }^{1,2}$, Yanli Zhang ${ }^{1,2}$ and \\ Feng Wang ${ }^{1,2}$ \\ ${ }^{1}$ Institute of Sheep and Goat Science and ${ }^{2}$ Center of Animal Embryo Engineering and Technology, Nanjing Agricultural \\ University, Jiangsu, Nanjing 210095, China
}

Correspondence should be addressed to F Wang at Institute of Sheep and Goat Science, Nanjing Agricultural University; Email: caeet@njau.edu.cn

\begin{abstract}
This study investigated the effects of short-term food restriction or supplementation on folliculogenesis and plasma and intrafollicular metabolite and hormone concentrations. Ewes were randomly assigned to three groups: the control group received a maintenance diet (M) while the supplemented group and restricted group received $1.5 \times M$ and $0.5 \times M$ respectively on days 6-12 of their estrous cycle. Estrus was synchronized by intravaginal progestogen sponges for 12 days. On days 7-12, blood samples were taken. After slaughter, the ovarian follicles were classified and the follicular fluid was collected. Compared with restriction, supplementation shortened the estrous cycle length, decreased the number of follicles 2.5-3.5 mm and follicular fluid estradiol $\left(E_{2}\right)$ concentration, increased the number of follicles $>3.5 \mathrm{~mm}$ and plasma glucose, insulin and glucagon concentrations, and augmented the volume of follicles $>2.5 \mathrm{~mm}$.

Restricted ewes had higher intrafollicular insulin concentration, but it was similar to that of supplemented ewes. Compared with follicles $\leq 2.5 \mathrm{~mm}$, the intrafollicular glucose and $E_{2}$ concentrations were increased and the testosterone, insulin, and glucagon concentrations and lactate dehydrogenase (LDH) activity were decreased in follicles $>2.5 \mathrm{~mm}$. Only in restricted ewes were intrafollicular LDH and testosterone concentrations in follicles $\leq \mathbf{2 . 5} \mathbf{~ m m}$ not different from those in follicles $\leq \mathbf{2 . 5} \mathbf{~ m m}$. In conclusion, the mechanism by which short-term dietary restriction inhibits folliculogenesis may involve responses to intrafollicular increased $\mathrm{E}_{2}$, testosterone, and LDH levels in late-stage follicles. This may not be due to the variation of intrafollicular insulin level but rather due to decreased circulating levels of glucose, insulin, and glucagon.

Reproduction (2011) 142 699-710
\end{abstract}

\section{Introduction}

Nutrition is one of the most important environmental factors associated with the reproductive performance of sheep. Many studies reported that short-term nutritional supplementation stimulated follicle development or ovulation rate (Teleni et al. 1989, Downing \& Scaramuzzi 1991, Downing et al. 1995a, 1995c, van Barneveld 1999, Munoz-Gutierrez et al. 2002, Viñoles et al. 2005, Somchit et al. 2007). The current theory regarding the immediate effect of nutrition on folliculogenesis is that metabolites and metabolic hormones act as signals directly on follicles to regulate folliculogenesis (Scaramuzzi et al. 1993, Downing et al. 1995a, 1995b, 1995c, Scaramuzzi et al. 2006), since glucose transporter proteins and specific receptors are present in the follicles (Williams et al. 2001, Munoz-Gutierrez et al. 2004, Sutton-McDowall et al. 2010); however, there was little information about follicular fluid responses to the short-term nutritional treatment.

Since the somatic and germ cells are in contact with follicular fluid, the follicular microenvironment has long been suspected of playing a critical role in the differentiation and steroidogenic capacity of ovarian cells and determining follicular fate (Avery et al. 2003, Fortune et al. 2004). Short-term nutritional treatment increased the plasma concentrations of glucose and insulin (Teleni et al. 1989, Downing \& Scaramuzzi 1991, Downing et al. 1995a, 1995b, 1995c, van Barneveld 1999, Viñoles et al. 2005, Alexander et al. 2007), 
elevated intrafollicular glucose concentration, and lowered progesterone concentration in small follicles, but it did not affected estradiol $\left(E_{2}\right)$ secretion (Somchit et al. 2007). Glucose consumed by follicles can be used for energy production, cellular homeostasis, nuclear maturation, and as substrates for matrix production to maintain follicle development (Sutton-McDowall et al. 2010). Insulin, on the one hand, increases the ability of the follicular cells to take up glucose (Williams et al. 2001) to indirectly regulate follicular growth and, on the other hand, directly acts on folliculogenesis (Downing \& Scaramuzzi 1995).

An alternative mechanism of the immediate nutritional effect on follicle development might involve nutritional direct actions at the ovarian level by influencing the number of follicles escaping atresia. Atresia was evident at all stages of the estrus cycle in ewes (Brand \& de Jong 1973, Turnbull et al. 1977). In the later stages of follicular atresia, testosterone concentration was elevated (Moor et al. 1978, Carson et al. 1981). Lactate dehydrogenase (LDH) was present in almost all cells and was thought to be a clear indicator of cell destruction (Franke et al. 2010). Previous studies in heifers indicate that LDH activity tended to be higher in atretic follicles and decreased as follicle size increased (Wise et al. 1987). Nandi et al. (2007) also reported that as follicles became larger, the concentration of follicular fluid LDH significantly decreased in non-pregnant slaughtered sheep. LDH activity tended to be increased in atretic follicles or smaller follicles. Glucagon, released from pancreatic $\alpha$ cells, is the principal counterregulatory hormone that opposes the action of insulin by promoting hepatic glycogenolysis, gluconeogenesis, and ketogenesis and its receptor was present in ovary (Hansen et al. 1995, Heurich et al. 1996, Cascieri et al. 1999, Wang et al. 2008). It might improve reproductive performance indirectly by increasing concentrations of plasma glucose and insulin (Bobe et al. 2007). We propose that immediate restriction inhibited follicular growth and affected intrafollicular endocrine and metabolic milieu by decreased circulating glucose, insulin, and glucagon concentrations.

Therefore, this study was designed to test whether short-term supplementation or restriction of feed intake on days 6-12 of the cycle affects follicle development through changing the circulating concentrations of glucose and metabolic hormones and influencing the intrafollicular microenvironment in Hu sheep.

\section{Results}

\section{Body weight and body condition score}

The average body weight and body condition score are shown in Table 1 . There were no significant differences in the body weight and body condition score among times or treatments, but body weight was higher in the
Table 1 The average body weight and body condition score in the three treatment groups.

\begin{tabular}{llll}
\hline Parameters & $\mathbf{R}(n=16)$ & $\mathbf{C}(n=6)$ & $\mathbf{S}(n=16)$ \\
\hline Body weight (kg) & & & \\
$\quad$ Pessary insertion & $41.8 \pm 0.9$ & $41.1 \pm 0.3$ & $40.9 \pm 0.9$ \\
Pessary removal & $41.5 \pm 0.9$ & $41.7 \pm 0.4$ & $40.8 \pm 0.9$ \\
Start of nutritional levels & $42.3 \pm 0.9$ & $41.7 \pm 0.4$ & $40.9 \pm 0.8$ \\
$\quad$ Slaughter & $40.1 \pm 0.9^{\mathrm{b}}$ & $41.2 \pm 0.4^{\mathrm{ab}}$ & $43.3 \pm 0.7^{\mathrm{a}}$ \\
Body condition score (unit) & & & \\
$\quad$ Pessary insertion & $2.61 \pm 0.08$ & $2.58 \pm 0.12$ & $2.55 \pm 0.09$ \\
Pessary removal & $2.53 \pm 0.07$ & $2.29 \pm 0.15$ & $2.45 \pm 0.12$ \\
Start of nutritional levels & $2.48 \pm 0.08$ & $2.45 \pm 0.10$ & $2.43 \pm 0.09$ \\
Slaughter & $2.45 \pm 0.06$ & $2.54 \pm 0.18$ & $2.52 \pm 0.10$ \\
& & &
\end{tabular}

$\mathrm{R}$ indicates the restricted group; $\mathrm{C}$ indicates the control group; $\mathrm{S}$ indicates the supplemented group. Values with different superscripts with rows differ significantly $(P<0.05)$.

$\mathrm{S}$ group than in the $\mathrm{R}$ group $(P<0.05)$ at the time of slaughter due to the increased ruminal and intestinal content $(P<0.05$; data not presented).

\section{Number and distribution of ovarian follicles}

Every ewe had at least two corpora lutea $(\mathrm{CL})$, confirming that the ewes were, as expected, in the luteal phase of the estrous cycle. The average number of $C L$ per ewe in $\mathrm{R}$ $(n=11), \mathrm{C}(n=6)$, and $\mathrm{S}(n=11)$ groups was $2.64 \pm 0.15$, $2.50 \pm 0.22$, and $2.45 \pm 0.69$ respectively. The first estrus in the $\mathrm{R}$ group ewes $(n=5$; the mean estrous cycle: $17.7 \pm 1.1$ days) was delayed compared with that in the $S$ group ewes $(n=5$; the mean estrous cycle: $15.8 \pm 0.27$ days; $P<0.05)$. The follicles dissected from the ovaries of $\mathrm{R}(n=6), \mathrm{C}(n=6)$, and $\mathrm{S}(n=6)$ group ewes are shown in Table 2. There was no effect of treatment on the number of follicles in the $2.0-2.5 \mathrm{~mm}$ size class. However, the mean number of follicles increased in the $\geq 3.5 \mathrm{~mm}$ class and decreased in the

Table 2 The mean volume, number, and size distribution of the follicles dissected from the ovaries from three groups of Hu sheep with different feeding level for 6 days.

\begin{tabular}{lcccc}
\hline Parameters & $\begin{array}{c}\text { Follicle class } \\
(\text { diameter } \\
(\mathrm{mm}))\end{array}$ & $\mathbf{R}(n=6)$ & $\mathbf{C}(n=6)$ & $\mathbf{S}(n=6)$ \\
\hline NDF & $\geq 3.5$ & $0.17 \pm 0.17^{\mathrm{b}}$ & $0.5 \pm 0.34^{\mathrm{ab}}$ & $1.17 \pm 0.40^{\mathrm{a}}$ \\
& $2.5-3.5$ & $2.67 \pm 0.42^{\mathrm{a}}$ & $1.83 \pm 0.40^{\mathrm{ab}}$ & $1.67 \pm 0.33^{\mathrm{b}}$ \\
& $2.0-2.5$ & $2.33 \pm 0.72$ & $2.00 \pm 0.37$ & $3.33 \pm 0.72$ \\
$\mathrm{MVF}$ & $\geq 2.0$ & $5.17 \pm 0.87$ & $4.33 \pm 0.88$ & $6.17 \pm 0.60$ \\
& $\geq 3.5$ & 15.43 & $21.09 \pm 4.60$ & $17.21 \pm 1.23$ \\
& $2.5-3.5$ & $9.79 \pm 0.48$ & $10.15 \pm 0.43$ & $10.31 \pm 0.64$ \\
& $>2.5$ & $10.11 \pm 0.56^{\mathrm{b}}$ & $12.50 \pm 1.54^{\mathrm{ab}}$ & $13.15 \pm 1.04^{\mathrm{a}}$ \\
& $2.0-2.5$ & $3.88 \pm 0.18^{\mathrm{ab}}$ & $4.55 \pm 0.30^{\mathrm{a}}$ & $3.61 \pm 0.10^{\mathrm{b}}$ \\
& $1.0-2.0$ & $1.33 \pm 0.10^{\mathrm{b}}$ & $1.84 \pm 0.11^{\mathrm{a}}$ & $1.46 \pm 0.10^{\mathrm{b}}$ \\
& & & &
\end{tabular}

$\mathrm{R}$ indicates the restricted group; $\mathrm{C}$ indicates the control group; $\mathrm{S}$ indicates the supplemented group. NDF indicates number and size distribution of the follicles; MDF indicates mean diameter of the follicles. Values with different superscripts with rows differ significantly $(P<0.05)$. 


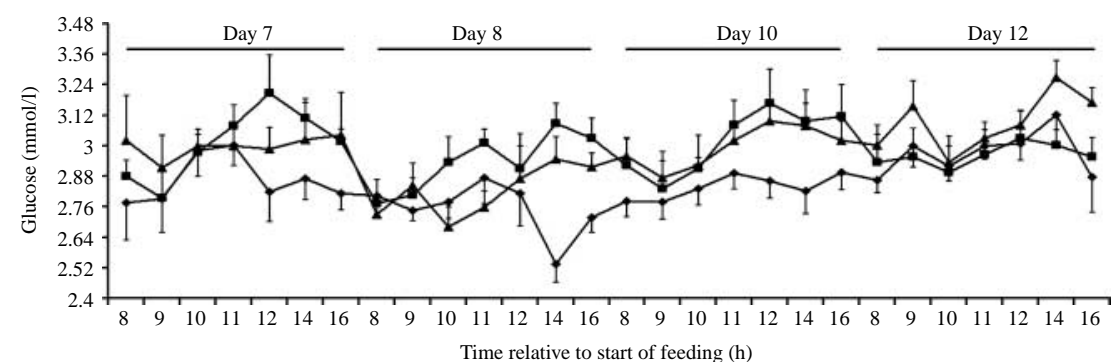

Figure 1 Mean blood concentrations of glucose during the first (day 7), second (day 8), fourth (day 10), and sixth (day 12) days after the start of a short-term different nutritional intake in $\mathrm{R}$ group ewes fed $0.5 \times$ maintenance diet (filled diamond; $n=6$ ), $C$ group ewes fed a maintenance diet (filled square; $n=6$ ), and $S$ group ewes fed $1.5 \times$ maintenance diet (filled triangle; $n=6$ ).

2.5-3.5 mm class as intake increased $(P<0.05$; Table 2$)$. $\mathrm{R}$ group ewes had more follicles $2.5-3.5 \mathrm{~mm}$ in diameter $(P<0.05)$, but fewer follicles $\geq 3.5 \mathrm{~mm}$ class $(P<0.05)$. There was no effect of treatment on the mean volume of follicles in 2.5-3.5 mm size classes; however, there were significant effects of treatment on the mean volume of follicles in 1.0-2.0, 2.0-2.5, and $>2.5 \mathrm{~mm}$ size classes $(P<0.05 ;$ Table 2$)$. The mean volume of follicles in the $>2.5 \mathrm{~mm}$ significantly increased as intake increased (Table 2). The mean volume of follicles 1.0-2.0 and $2.0-2.5 \mathrm{~mm}$ in the $\mathrm{R}$ group ewes was similar to that in the $S$ group ewes.

\section{Plasma glucose, insulin, and glucagon concentrations}

The plasma glucose concentrations are shown in Fig. 1 and Table 3. There were significant effects of treatment, day and time on blood glucose concentration $(P<0.001)$, and the treatment by day $(P<0.05)$ and treatment by time interactions $(P<0.001)$ were significant. The mean blood concentrations of glucose for $\mathrm{R}$ group ewes were significantly lower than that of the $C$ and $\mathrm{S}$ group ewes $(P<0.001 ;$ Table 3$)$. The mean concentration of glucose on day 7 was similar among the three groups. Glucose concentrations on day 8 were higher in $\mathrm{C}$ than in $\mathrm{R}$ and $\mathrm{S}$ group ewes $(P<0.001)$ and on day 10 were higher in $C$ and $S$ group than $R$ ewe $(P<0.01)$. However, glucose concentrations on day 12 were higher in $\mathrm{S}$ than in the $\mathrm{C}$ and $\mathrm{R}$ group ewes $(P<0.05)$. In the $\mathrm{R}$ group, the mean glucose concentrations were similar on days 7,8 , and 10 but increased on day 12 compared with days $8(P<0.001)$ and 10 $(P<0.05)$. In the $C$ group, the mean concentrations of glucose were similar on days $7,8,10$, and 12 . In the $S$ group, glucose concentrations on day 8 were lower than on days 7,10 , and $12(P<0.01)$.
The plasma insulin concentrations are shown in Fig. 2 and Table 3. The mean concentrations of plasma insulin were higher in the $S$ group compared with the $\mathrm{R} \quad(P<0.01)$ and $\mathrm{C}(P<0.05)$ groups. There was a significant effect of time $(P<0.01)$ on plasma insulin concentration. The mean concentrations of insulin in the $R$ group varied significantly between days 9 and 10 $(P<0.05)$.

The plasma glucagon concentrations are shown in Fig. 2 and Table 3. The mean blood concentrations of glucagon increased as nutritional intake increased $(P<0.001)$. There was a significant effect of time $(P<0.05)$ on plasma glucagon concentrations.

\section{Follicular fluid glucose and urea concentrations}

The follicular fluid glucose and urea concentrations are shown in Fig. 3 and Table 4. There were no effects of treatment on the follicular fluid glucose and urea concentrations, and the treatment by follicle size interactions was also not significant $(P>0.05)$. There were no significant differences between follicles $>2.5$ and $\leq 2.5 \mathrm{~mm}$ in diameter within each group ewes; however, there was a significant effect of follicle size on the follicular fluid glucose concentration $(P<0.05)$.

\section{Follicular fluid insulin and glucagon concentrations}

The follicular fluid insulin and glucagon concentrations are shown in Fig. 3 and Table 4. There were significant effects of treatment $(P<0.01)$ and follicle size $(P<0.05)$ on the follicular fluid insulin concentration. The treatment by follicle size interaction was not significant $(P>0.05)$. The mean follicular fluid concentrations of insulin in $\mathrm{R}$ and $\mathrm{S}$ group ewes were similar but greater than in $\mathrm{C}$ group ewes $(P<0.05)$. The mean follicular fluid

Table 3 Plasma concentrations of glucose, insulin, and glucagon from three groups of Hu sheep fed different nutritional diet for 6 days.

\begin{tabular}{|c|c|c|c|c|c|c|c|}
\hline \multirow[b]{2}{*}{ Treatment } & \multicolumn{5}{|c|}{ Glucose (mmol/l) } & \multirow[b]{2}{*}{ Insulin $(\mu \mathrm{IU} / \mathrm{ml})$} & \multirow[b]{2}{*}{ Glucagon $(\mathrm{pg} / \mathrm{ml})$} \\
\hline & Total & Days 7 & Days 8 & Days 10 & Days 12 & & \\
\hline $\mathrm{R}$ & $2.86 \pm 0.02^{\mathrm{B}}$ & $2.87 \pm 0.04^{b}$ & $2.75 \pm 0.03^{\mathrm{B}, \mathrm{c}}$ & $2.84 \pm 0.03^{\mathrm{B}, \mathrm{b}}$ & $2.97 \pm 0.03^{\mathrm{B}, \mathrm{a}}$ & $13.69 \pm 0.48^{\mathrm{B}}$ & $99.12 \pm 7.96^{\mathrm{C}}$ \\
\hline C & $2.98 \pm 0.02^{\mathrm{A}}$ & $3.01 \pm 0.04$ & $2.94 \pm 0.03^{\mathrm{A}}$ & $3.00 \pm 0.03^{\mathrm{A}}$ & $2.96 \pm 0.03^{\mathrm{B}}$ & $14.31 \pm 0.48^{\mathrm{B}}$ & $132.46 \pm 7.96^{\mathrm{B}}$ \\
\hline$S$ & $2.98 \pm 0.02^{\mathrm{A}}$ & $3.00 \pm 0.04^{\mathrm{a}}$ & $2.82 \pm 0.03^{\mathrm{B}, \mathrm{b}}$ & $3.00 \pm 0.03^{\mathrm{A}, \mathrm{a}}$ & $3.09 \pm 0.03^{\mathrm{A}, \mathrm{a}}$ & $15.95 \pm 0.44^{\mathrm{A}}$ & $199.46 \pm 7.26^{\mathrm{A}}$ \\
\hline
\end{tabular}

$\mathrm{R}$ indicates the restricted group; $\mathrm{C}$ indicates the control group; $\mathrm{S}$ indicates the supplemented group. Significant differences are indicated with capital letters in the same column and small letters in the same row; different letters mean significant difference $(P<0.05)$, the same letter or no letter means no significant difference $(P>0.05)$. 

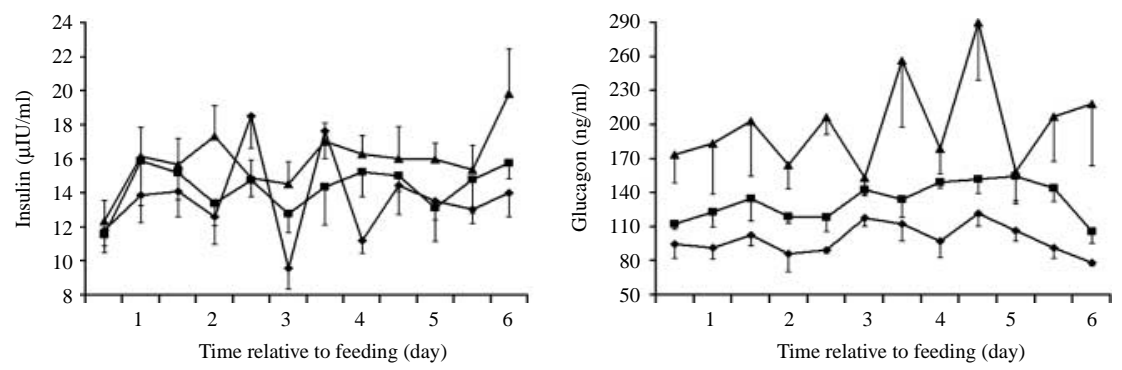

Figure 2 Changes in the concentrations of plasma insulin and glucagon from three groups of Hu sheep after the start of a short-term different nutritional intake in $\mathrm{R}$ group ewes fed $0.5 \times$ maintenance diet (filled diamond; $n=5$ ), $C$ group ewes fed a maintenance diet (filled square; $n=5$ ), and $S$ group ewes fed $1.5 \times$ maintenance diet (filled triangle; $n=6$ ) for 6 days. insulin concentration was higher in follicles $\leq 2.5 \mathrm{~mm}$ than in follicles $>2.5 \mathrm{~mm}(P<0.05)$; however, only in $\mathrm{R}$ group ewes did the mean follicular fluid insulin concentration increase in follicles $\leq 2.5 \mathrm{~mm}(P<0.05)$.

There was a significant effect of follicle size $(P<0.05)$ but not of treatment $(P>0.05)$ on the follicular fluid glucagon concentration. The treatment by follicle size interaction was not significant $(P>0.05)$. The mean follicular fluid glucagon concentration was higher in follicles $\leq 2.5 \mathrm{~mm}$ than in follicles $>2.5 \mathrm{~mm}(P<0.05)$; however, only in $C$ group ewes did the mean follicular fluid glucagon concentration increase in follicles $\leq 2.5 \mathrm{~mm}(P<0.05)$.

\section{Follicular fluid $E_{2}$, progesterone, testosterone, and LDH concentrations}

The follicular fluid $E_{2}$, progesterone, testosterone, and $\mathrm{LDH}$ concentrations are shown in Fig. 3 and Table 4. There were significant effects of treatment $(P<0.05)$ and follicle size $(P<0.001)$ on the mean follicular fluid concentration of $E_{2}$. The treatment by follicle size interaction was significant $(P<0.05)$. The mean follicular fluid concentration of $E_{2}$ decreased as intake increased. $\mathrm{R}$ group ewes had higher concentrations than the $S$ group $(P<0.05)$. The mean follicular fluid concentration of $E_{2}$ in each group was significantly higher in follicles $>2.5 \mathrm{~mm}$ in diameter compared with those $\leq 2.5 \mathrm{~mm}$ in diameter $(P<0.05)$. The mean follicular fluid concentration of $E_{2}$ in follicles $>2.5 \mathrm{~mm}$ in diameter in $\mathrm{R}(41.61 \pm 6.99 \mathrm{ng} / \mathrm{ml})$ and $\mathrm{S}(21.19$ $\pm 4.71 \mathrm{ng} / \mathrm{ml}$ ) groups were significantly different $(P<0.05)$. CYP19A1 mRNA expression in follicular cells, associated with follicular fluid $E_{2}$ secretion, was also increased as dietary intake decreased at the same time $(P<0.05$; Fig. 4 and Table 5).

There were no effects of follicle size $(P>0.05)$ or treatment $(P>0.05)$ on the follicular fluid concentration of progesterone. The treatment by follicle size interaction was not significant $(P>0.05)$. There were no significant differences between follicles $>2.5$ and $\leq 2.5 \mathrm{~mm}$ in diameter within each group ewes $(P>0.05)$. STAR and CYP11A1 mRNA expression, implicated in progesterone synthesis, were also affected at the same time $(P<0.05$; Fig. 4 and Table 5).

There were significant effects of follicle size $(P<0.01)$ but not of treatment $(P>0.05)$ on the follicular fluid concentrations of testosterone and $\mathrm{LDH}$. The treatment by follicle size interactions was not significant $(P>0.05)$. The mean follicular fluid testosterone and LDH concentrations were higher in follicles $\leq 2.5 \mathrm{~mm}$ than in follicles $>2.5 \mathrm{~mm}(P<0.05)$; however, only in $\mathrm{R}$ group ewes were the mean follicular fluid testosterone and $\mathrm{LDH}$ concentrations in follicles $\leq 2.5 \mathrm{~mm}$ similar to those in follicles $>2.5 \mathrm{~mm}$ in diameter $(P<0.05)$.

\section{Correlation of follicle size with metabolites and hormones}

A multiple regression model was set in order to explaining a good proportion of variation in follicle size among ewes during luteal phase. Follicle diameter was set as the dependent variable. Follicular fluid LDH activity and glucose, glucagon, $\mathrm{E}_{2}$, testosterone, insulin, urea, and progesterone concentrations were entered into the model as independent variable. The results showed that $66.8 \%$ variation (as determined by $R^{2}$ ) in follicle size was explained by follicular fluid $\operatorname{LDH}(\beta=-0.583$,
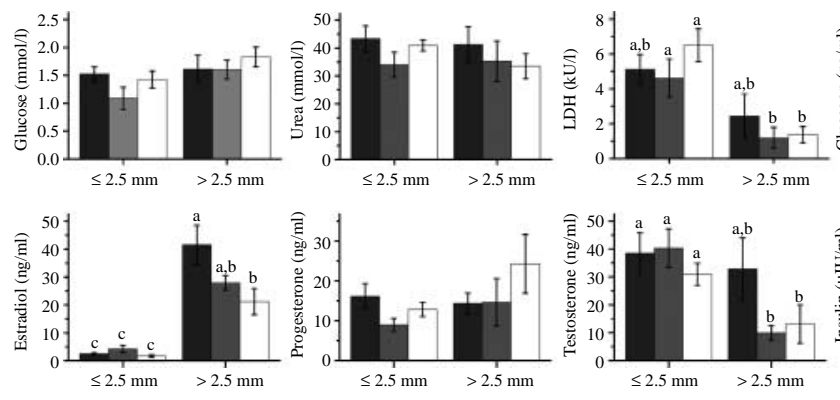

Follicle diameter
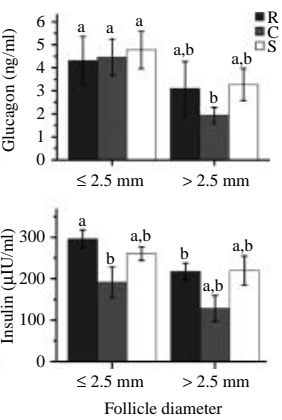

Figure 3 The mean concentrations of glucose, urea, LDH, glucagon, estradiol, progesterone, testosterone, and insulin in follicular fluid from follicles $\leq 2.5$ and $>2.5 \mathrm{~mm}$ in diameter from three groups of Hu sheep fed $0.5 \times$ maintenance diet (R group; $n=6$ ), a maintenance diet (C group; $n=5)$, or $1.5 \times$ maintenance diet $(S$ group; $n=6$ ) for 6 days. Columns with different letters are significantly different at $P<0.05$. 
Table 4 The mean follicular fluid concentrations of metabolites, lactate dehydrogenase (LDH), and hormones from Hu sheep fed different nutritional intake for 6 days in $\mathrm{R}, \mathrm{C}$, and $\mathrm{S}$ group ewes.

\begin{tabular}{|c|c|c|c|c|c|}
\hline Parameters & Follicle size & $\mathbf{R}$ & C & $\mathbf{S}$ & Total \\
\hline \multirow[t]{3}{*}{ Glucose (mmol/l) } & $\leq 2.5 \mathrm{~mm}$ & $1.53 \pm 0.13$ & $1.09 \pm 0.20$ & $1.43 \pm 0.15$ & $1.36 \pm 0.10^{b}$ \\
\hline & $>2.5 \mathrm{~mm}$ & $1.61 \pm 0.25$ & $1.60 \pm 0.17$ & $1.83 \pm 0.18$ & $1.69 \pm 0.11^{\mathrm{a}}$ \\
\hline & Total & $1.57 \pm 0.13$ & $1.35 \pm 0.14$ & $1.63 \pm 0.13$ & \\
\hline \multirow{3}{*}{ Urea (mmol/l) } & $\leq 2.5 \mathrm{~mm}$ & $43.36 \pm 4.65$ & $34.02 \pm 4.50$ & $40.91 \pm 2.00$ & $39.74 \pm 2.29$ \\
\hline & $>2.5 \mathrm{~mm}$ & $41.27 \pm 6.35$ & $35.29 \pm 7.21$ & $33.52 \pm 4.52$ & $36.78 \pm 3.35$ \\
\hline & Total & $42.31 \pm 3.46$ & $34.65 \pm 3.79$ & $37.21 \pm 3.46$ & \\
\hline \multirow[t]{3}{*}{ LDH (kU/l) } & $\leq 2.5 \mathrm{~mm}$ & $5.12 \pm 0.85$ & $4.61 \pm 1.09^{\mathrm{a}}$ & $6.50 \pm 0.95^{\mathrm{a}}$ & $5.46 \pm 0.55^{\mathrm{a}}$ \\
\hline & $>2.5 \mathrm{~mm}$ & $2.44 \pm 1.28$ & $1.19 \pm 0.61^{b}$ & $1.37 \pm 0.47^{\mathrm{b}}$ & $1.69 \pm 0.50^{\mathrm{b}}$ \\
\hline & Total & $3.78 \pm 0.64$ & $2.90 \pm 0.70$ & $3.94 \pm 0.64$ & \\
\hline \multirow[t]{3}{*}{ Insulin $(\mu \mathrm{IU} / \mathrm{ml})$} & $\leq 2.5 \mathrm{~mm}$ & $295.98 \pm 21.56^{\mathrm{A}, \mathrm{a}}$ & $191.30 \pm 36.78^{\mathrm{B}}$ & $260.27 \pm 16.44^{\mathrm{AB}}$ & $252.59 \pm 17.10^{a}$ \\
\hline & $>2.5 \mathrm{~mm}$ & $217.22 \pm 20.70^{b}$ & $128.28 \pm 31.46$ & $219.52 \pm 35.09$ & $191.87 \pm 19.01^{\mathrm{b}}$ \\
\hline & Total & $256.60 \pm 18.79^{\mathrm{A}}$ & $159.79 \pm 20.59^{\mathrm{B}}$ & $239.89 \pm 18.79^{\mathrm{A}}$ & \\
\hline \multirow[t]{3}{*}{ Glucagon (ng/ml) } & $\leq 2.5 \mathrm{~mm}$ & $4.31 \pm 1.05$ & $4.46 \pm 0.79^{\mathrm{a}}$ & $4.78 \pm 0.81$ & $4.52 \pm 0.49^{\mathrm{a}}$ \\
\hline & $>2.5 \mathrm{~mm}$ & $3.10 \pm 1.17$ & $1.94 \pm 0.34^{\mathrm{b}}$ & $3.27 \pm 0.70$ & $2.87 \pm 0.47^{\mathrm{b}}$ \\
\hline & Total & $3.71 \pm 0.61$ & $3.20 \pm 0.66$ & $4.02 \pm 0.61$ & \\
\hline \multirow[t]{3}{*}{ Estradiol (ng/ml) } & $\leq 2.5 \mathrm{~mm}$ & $2.51 \pm 0.29^{b}$ & $4.23 \pm 1.29^{\mathrm{b}}$ & $1.68 \pm 0.47^{\mathrm{b}}$ & $2.72 \pm 0.47^{b}$ \\
\hline & $>2.5 \mathrm{~mm}$ & $41.61 \pm 6.99^{\mathrm{A}, \mathrm{a}}$ & $27.91 \pm 2.6^{\mathrm{AB}, \mathrm{a}}$ & $21.19 \pm 4.71^{\mathrm{B}, \mathrm{a}}$ & $30.37 \pm 3.62^{\mathrm{a}}$ \\
\hline & Total & $22.06 \pm 2.62^{\mathrm{A}}$ & $16.07 \pm 2.87^{\mathrm{AB}}$ & $11.43 \pm 2.62^{\mathrm{B}}$ & \\
\hline \multirow[t]{3}{*}{ Progesterone (ng/ml) } & $\leq 2.5 \mathrm{~mm}$ & $16.12 \pm 3.21$ & $8.97 \pm 1.60$ & $12.83 \pm 1.78$ & $12.86 \pm 1.48$ \\
\hline & $>2.5 \mathrm{~mm}$ & $14.37 \pm 2.56$ & $14.65 \pm 5.98$ & $24.27 \pm 7.39$ & $18.53 \pm 3.14$ \\
\hline & Total & $15.25 \pm 3.00$ & $11.81 \pm 3.28$ & $18.55 \pm 3.00$ & \\
\hline \multirow[t]{3}{*}{ Testosterone (ng/ml) } & $\leq 2.5 \mathrm{~mm}$ & $38.50 \pm 7.37$ & $40.31 \pm 6.90^{\mathrm{a}}$ & $30.92 \pm 3.96^{\mathrm{a}}$ & $36.35 \pm 3.50^{\mathrm{a}}$ \\
\hline & $>2.5 \mathrm{~mm}$ & $32.88 \pm 11.13$ & $9.95 \pm 2.62^{b}$ & $13.08 \pm 6.90^{\mathrm{b}}$ & $19.15 \pm 5.09^{b}$ \\
\hline & Total & $35.69 \pm 4.98$ & $25.13 \pm 5.45$ & $22.00 \pm 4.98$ & \\
\hline
\end{tabular}

$\mathrm{R}$ indicates the restricted group; $\mathrm{C}$ indicates the control group; $\mathrm{S}$ indicates the supplemented group. Significant differences are indicated with capital letters in the same row and small letters in the same column for each parameter; different letters mean significant difference $(P<0.05)$, the same letter or no letter means no significant difference $(P>0.05)$.

$P<0.001)$ activity and urea $(\beta=-0.345, P<0.001)$, glucose $(\beta=0.342, \quad P<0.001)$, and $\mathrm{E}_{2} \quad(\beta=0.300$, $P<0.001)$ concentrations. The follicular diameter was predicted using the following formula: $D=2.886-$ $0.129(\mathrm{LDH})+0.09\left(\mathrm{E}_{2}\right)-0.014$ (urea) +0.275 (glucose) where $D$ is the follicle diameter $(\mathrm{mm})$.

\section{Discussion}

Prolonged dietary restriction results in cessation of the estrous cycle in domestic animals (Richards et al. 1989, Tanaka et al. 2004). The result of this study shows that the first estrus was significantly delayed in restricted group ewes and that folliculogenesis was affected by short-term changes in feed intake during the luteal phase of the estrous cycle (Table 2). These effects might be associated with changed plasma glucose, insulin and glucagon levels, and the follicular metabolic and endocrine milieu.
Short-term supplementation before luteolysis significantly affected folliculogenesis in the follicular phase (Munoz-Gutierrez et al. 2002, Viñoles et al. 2005) but not in the luteal phase (Nottle et al. 1985, Somchit et al. 2007). This study shows that the volume significantly increased in the $>2.5 \mathrm{~mm}$ class, the number of follicles 2.5-3.5 $\mathrm{mm}$ was decreased, and the number of follicles $\geq 3.5 \mathrm{~mm}$ increased as feed intake increased (Table 2), indicating that there were different responses to shortterm different nutritional intake during luteal phase for different classified follicles. A potential mechanism of short-term nutritional effect on folliculogenesis is that supplementation increased the number of follicles escaping atresia. Ovarian follicles preferentially undergo atresia during luteal phase in ewes (Viñoles 2003) and the last non-ovulatory follicle had a longer lifespan when short-term supplementation (Viñoles et al. 2005). We speculated that short-term restricted intake inhibited follicles $2.5-3.5 \mathrm{~mm}$ from further development and
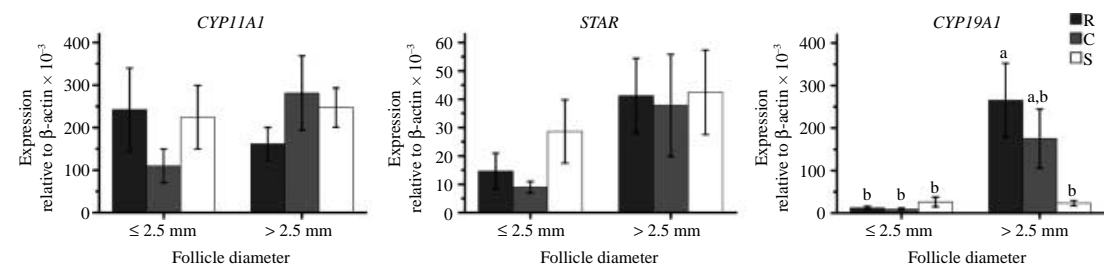

Figure 4 The gene expression of CYP11A1, STAR, and CYP19A1 mRNA in follicular cells from follicles $\leq 2.5$ and $>2.5 \mathrm{~mm}$ in diameter from three groups of Hu sheep fed $0.5 \times$ maintenance diet (R group; $n=6$ ), a maintenance diet (C group; $n=5)$, or $1.5 \times$ maintenance diet (S group; $n=6)$ for 6 days. Columns with different letters are significantly different at $P<0.05$. 
Table 5 The gene expression of CYP11A1, STAR, and CYP19A1 mRNA in follicular cells from Hu sheep fed different nutritional intake for 6 days in R, $\mathrm{C}$, and $\mathrm{S}$ group ewes.

\begin{tabular}{llccrr}
\hline Genes & Follicle size & R & C & S & Total \\
\hline CYP19A1 & $\leq 2.5 \mathrm{~mm}$ & $12.18 \pm 3.75^{\mathrm{b}}$ & $9.23 \pm 2.41$ & $26.23 \pm 11.20$ & $17.09 \pm 4.81^{\mathrm{b}}$ \\
& $>2.5 \mathrm{~mm}$ & $265.32 \pm 86.81^{\mathrm{Aa}}$ & $175.25 \pm 69.49^{\mathrm{AB}}$ & $23.17 \pm 6.13^{\mathrm{B}}$ & $150.45 \pm 42.33^{\mathrm{a}}$ \\
STAR & Total & $145.41 \pm 53.60^{\mathrm{A}}$ & $84.70 \pm 39.53^{\mathrm{AB}}$ & $24.70 \pm 6.22^{\mathrm{A}}$ & \\
& $\leq 2.5 \mathrm{~mm}$ & $14.62 \pm 6.32$ & $8.95 \pm 2.02$ & $28.62 \pm 11.20$ & $18.86 \pm 5.16$ \\
& $>2.5 \mathrm{~mm}$ & $41.22 \pm 13.21$ & $37.84 \pm 18.03$ & $42.42 \pm 14.92$ & $41.02 \pm 8.40$ \\
CYP11A1 & Total & $28.62 \pm 8.01$ & $22.08 \pm 8.99$ & $35.52 \pm 9.22$ & $203.27 \pm 46.78$ \\
& $\leq 2.5 \mathrm{~mm}$ & $242.03 \pm 98.05$ & $109.94 \pm 39.93$ & $224.39 \pm 74.76$ & $219.66 \pm 30.02$ \\
& $>2.5 \mathrm{~mm}$ & $161.55 \pm 38.76$ & $281.17 \pm 87.42$ & $247.01 \pm 46.26$ & $23.70 \pm 42.86$
\end{tabular}

The data are presented as mean \pm S.E.M. (relative to $\beta$-actin $\times 10^{-3}$ units). $\mathrm{R}$ indicates the restricted group; $\mathrm{C}$ indicates the control group; $\mathrm{S}$ indicates the supplemented group. Significant differences are indicated with capital letters in the same row and small letters in the same column for each parameter; different letters mean significant difference $(P<0.05)$, the same letter or no letter means no significant difference $(P>0.05)$.

increased the number of follicles $\geq 3.5 \mathrm{~mm}$ undergoing atresia, while supplementation delayed the occurrence of atresia in follicles $\geq 3.5 \mathrm{~mm}$. Our study was consistent with other studies, showing that short-term different dietary intake has an 'acute' effect on folliculogenesis without a changed live weight or body condition (Table 1). These results suggest that ovaries respond to nutritional signals rather than body weight or body condition.

Short-term infusion of glucose during the luteal phase of the estrous cycle stimulated folliculogenesis (Downing et al. 1995c, Munoz-Gutierrez et al. 2002), which further confirmed the effect of energy on folliculogenesis. Insulin was a nutritional mediator regulating folliculogenesis (Downing \& Scaramuzzi 1995, Downing et al. 1999). Glucagon is a key hormone in glucose homeostasis acting to promote gluconeogenesis and increase glucose output from liver by increasing hepatic glycogenolysis and gluconeogenesis and by promoting ketogenesis and might improve reproductive performance indirectly by increasing concentrations of plasma glucose and insulin (Bobe et al. 2007). The data from this study show that the plasma concentrations of glucose, insulin, and glucagon were significantly decreased in R group ewes (Figs 1 and 2; Table 3) and folliculogenesis and estrous cycle length were affected between the $\mathrm{R}$ and $\mathrm{S}$ groups (Table 2). The influenced folliculogenesis and estrous cycle length might have been induced by changes in circulating glucose, insulin, and glucagon levels and maybe it is not the sufficient energy, when short-term 1.5 M intake was administered, to significantly affect folliculogenesis.

The nutritional signals were speculated to directly regulate folliculogenesis at the ovarian level by affecting follicular atresia (Downing et al. 1999, Munoz-Gutierrez et al. 2002, Viñoles et al. 2005, Somchit et al. 2007), thereby increasing the pool of ovulatory follicles. To our knowledge, this is the first study investigating the association between folliculogenesis and intrafollicular metabolic and endocrine milieu, when being in the short-term different nutritional status. The present data show that short-term different dietary intake, along with changed circulating glucose, insulin, and glucagon levels, affected folliculogenesis and the intrafollicular environment.

Glucose consumed by follicles can be used for energy production, cellular homeostasis, nuclear maturation, substrates for matrix production, and as signals in four metabolic pathways: glycolysis, pentose phosphate pathway, hexosamine biosynthesis pathway, and the polyol pathway to maintain follicle development (Sutton-McDowall et al. 2010). In this study, glucose concentration in follicular fluid did not reflect the plasma glucose concentration and was lower than in blood (Tables 3 and 4), possibly due to different measurement methods of plasma and follicular fluid or rapid utilization of glucose within the follicular cells (Harris et al. 2005, Somchit et al. 2007). Concentrations of glucose significantly increased as follicles became larger, possibly because their energy requirement increased (Gull et al. 1999) or because of the different developmental stages of the follicles (Chang et al. 1976, Landau et al. 2000).

In this study, the follicular fluid insulin concentrations in $\mathrm{R}$ and $\mathrm{S}$ group ewes were higher than in the $\mathrm{C}$ group and only in follicles $\leq 2.5 \mathrm{~mm}$ did follicular fluid insulin concentration in follicles $>2.5 \mathrm{~mm}$ significantly increase (Fig. 3), which induced significantly decreased follicular fluid insulin concentration in follicles $>2.5 \mathrm{~mm}$ in diameter. Glucose is the major source of energy and metabolic substrate for follicle development (Scaramuzzi et al. 2010, Sutton-McDowall et al. 2010) and its entry rate to follicle cells increases as insulin increases, due to SLC2A4 (GLUT4), an insulin-dependent transporter with a high capacity for glucose transport, reported in granulosa and theca cells in ewes (Williams et al. 2001). Increased circulating insulin, regulating nutritional status, acts as a nutritional signal directly at the ovarian level to increase intrafollicular glucose uptake (Munoz-Gutierrez et al. 2002) or influence folliculogenesis by specific effects on granulosa and theca cell functions (Campbell et al. 1996, Yen et al. 2004). The lower circulating insulin concentration 
resulting from short-term restricted feed intake was not reflected in follicular fluid, suggesting that lower energy negatively feeds back and increases follicular fluid insulin concentration by inward transport to elevate the capacity of glucose uptake to maintain follicle development, especially in follicles $\leq 2.5 \mathrm{~mm}$ in diameter. Perhaps restricted intake affected folliculogenesis in $\mathrm{R}$ group ewes, not owing to the varied follicular fluid level of insulin, but rather owing to decreased circulating insulin level. The effects of intrafollicular increased insulin concentrations by short-term restriction and supplementation on folliculogenesis might be different.

Similarly to the plasma insulin concentration in our study, the concentration of glucagon in plasma was also not reflected in follicular fluid. No effects of nutrition on the follicular fluid glucagon concentration in the three groups were observed. Follicular fluid glucagon concentration was significantly decreased in follicles $>2.5 \mathrm{~mm}$ than in follicles $\leq 2.5 \mathrm{~mm}$; however, only in $\mathrm{C}$ group ewes was glucagon concentration significantly decreased (Fig. 3), indicating that follicular fluid glucagon concentration increased in $\mathrm{R}$ and $\mathrm{S}$ groups in follicles $>2.5 \mathrm{~mm}$ in diameter. The glucagon receptor has been reported in mammalian ovaries (Hansen et al. 1995, Heurich et al. 1996, Cascieri et al. 1999, Wang et al. 2008). Glucagon might have a novel physiological function in regulating folliculogenesis. However, a direct effect of glucagon on reproductive performance is probably minor because tissues in female reproductive organs have relative fewer glucagon receptors than liver, adipose tissue, heart, or kidney tissues (Hansen et al. 1995). Follicle development in $\mathrm{R}$ group ewes might be indirectly affected by circulating decreased glucagon level, but not by the direct intrafollicular pathway.

Follicular atresia was more common in small follicles and LDH activity tended to be increased in atretic follicles (Wise 1987), due to increased release of components from the cellular cytoplasm. Apoptosis of ovarian granulosa cells plays a major role in follicular atresia (Matsuda-Minehata et al. 2006). Thus, the measurement of follicular fluid LDH activity is important as a potential index of early follicular degeneration. In our study, the activity of LDH was reduced in follicular fluid as follicular size increased (Fig. 3), in accordance with previous studies (Wise 1987, Nandi et al. 2007). However, only in the R group was the activity of LDH not significantly decreased in follicles $>2.5 \mathrm{~mm}$ in diameter (Fig. 3), suggesting that restricted intake inhibited follicle development through increasing the number of apoptotic granulosa cells of follicles $>2.5 \mathrm{~mm}$ in diameter.

The effect of short-term supplementation on concentration of $\mathrm{E}_{2}$ during luteal phase is equivocal, with reports for (Downing et al. 1999, Munoz-Gutierrez et al. 2005) and against (Viñoles et al. 2005, Somchit et al. 2007) the induction of a change. In accordance with a previous study (Somchit et al. 2007), the follicular fluid concentration of $E_{2}$ was not affected by supplementation (Fig. 3).
However, restriction group ewes had a higher concentration of follicular fluid $E_{2}$ than the supplementation group ewes did (Fig. 3). Only ewes infused with a combination of glucose and insulin into the ovarian artery had decreased $E_{2}$ secretion during the luteal phase (Downing et al. 1999). Both plasma insulin and glucose concentrations in $\mathrm{S}$ group were significantly increased compared with R group (Figs 1 and 2) in our study. We proposed that follicular $\mathrm{E}_{2}$ secretion might be influenced through sufficient nutritional stimulation. During the whole developmental process, follicles sequentially become more sensitive to gonadotropins (Webb et al. 1999) and proper intrafollicular $E_{2}$ promotes follicular development and inhibits granulosa cell apoptosis (Rosenfeld et al. 2001). Ewes in high body condition have a large number of gonadotropin-dependent follicles and have higher ovulation rates, which are accompanied by lower $E_{2}$ and higher FSH concentrations during the follicular phase than ewes in low body condition (Rhind \& McNeilly 1986, Rhind et al. 1989, Zhengzhong et al. 1989, Viñoles et al. 2002). Sufficient exposure of antral follicles to FSH is the most critical stimulus for the follicles to escape atresia (Chun et al. 1996, Kaipia \& Hsueh 1997). Restriction inhibited folliculogenesis and elevated $\mathrm{E}_{2}$ level in follicles $>2.5 \mathrm{~mm}$ compared with supplementation (Table 2 and Fig. 3). We suggested that intrafollicular superfluous $E_{2}$ secretion in larger follicles inhibited folliculogenesis through stimulating FSH less in late-phase follicles, thus allowing few gonadotropin-responsive follicles to grow or increasing more number of atretic follicles.

In this study, the concentration of progesterone in follicular fluid was not affected by intake or follicle size in Hu sheep, which is an inconsistent effect of short-term supplementation with lupin grain (Somchit et al. 2007). This is possibly due to an insufficient response to nutrition by the $C L$ to secrete progesterone or insufficient energy to influence progesterone secretion during the luteal phase of the estrous cycle. The level of progesterone was not significantly different among atretic, slightly atretic, and healthy follicles (Yu et al. 2004), but testosterone elevated at all stages of follicular growth in the later stages of follicular atresia (Moor et al. 1978, Carson et al. 1981). The follicular fluid testosterone concentration was decreased in follicles $>2.5 \mathrm{~mm}$ except in R group ewes (Fig. 3), suggesting that inhibitory effect of short-term restriction on folliculogenesis might be expressed through stimulating atresia of large follicles. The changes in patterns of steroidogenesis that accompany atresia reflect some of the earliest changes in the functional capacity of follicles undergoing atresia (Carson et al. 1981). Thus, together with the findings of follicular $E_{2}$, progesterone, and testosterone concentrations and LDH activity variations, we propose that low nutritional intake stimulates atresia in follicles $>2.5 \mathrm{~mm}$ in diameter during the luteal phase, and this affects subsequent follicle development. 
We conclude that the mechanism by which short-term restriction inhibits folliculogenesis may involve responses to intrafollicular increased $E_{2}$, testosterone, and LDH levels in late-stage follicles, not to variation in intra-follicular insulin level. This effect may be due to decreased circulating levels of glucose, insulin, and glucagon.

\section{Materials and Methods}

\section{Animals}

The experiment was conducted at the Xuzhou Shen Ning Sheep \& Goat Farm (Jiangsu, China; longitude $117.94^{\circ}$ and latitude $33.89^{\circ}$ ) from May to July 2010 using 38 multiparous Hu sheep (3-4 years). The sheep weighed $40.4 \pm 0.5 \mathrm{~kg}$ and had body condition scores of $2.58 \pm 0.05$ units (scale: $0=$ emaciated to $5=$ obese (Russel et al. 1969)). Ewes were randomly assigned to three groups: the control group $(C ; n=6)$, the short-term supplemented group $(S ; n=16)$, and restriction group ( $R$; $n=16$ ). The animals were placed in individual pens (dimensions: $1.27 \times 2.55 \mathrm{~m}$ ) and pre-fed a maintenance diet for 7 days. After this time, a pessary was inserted.

During the experiment, the animals were maintained under natural photoperiod. The mean temperature inside the barn was $26.5 \pm 0.7,32.1 \pm 1.2$, and $26.4 \pm 0.6$ at 0800,1400 , and $2200 \mathrm{~h}$ respectively. During the experimental period, body condition and body weight were measured four times: at pessary insertion, at pessary removal, at the start of different feeds, and on the day they were killed. All experimental procedures were performed according to the guide for animal care and use of laboratory animals of the Institutional Animal Care and Use Committee of Nanjing Agricultural University.

\section{Diets}

All ewes received a total mixed ration diet. The diet ingredients and nutrient composition are shown in Table 6, based on feeding standards for meat-producing sheep and goats (NY/T

Table 6 The composition and nutrient contents of diet.

\begin{tabular}{lc}
\hline Item & Percentage of DM \\
\hline Ingredients & \\
Wheat straw & 66.85 \\
Cassava lees & 13.04 \\
Soybean meal & 4.12 \\
Wheat bran & 1.23 \\
Corn & 27.30 \\
Limestone $_{\text {CaHPO }}$ & 0.86 \\
Salt & 0.37 \\
Trace minerals and vitamins premix ${ }^{\mathrm{a}}$ & 0.65 \\
Chemical composition & \\
ME (MJ/day) & 0.27 \\
CP (g/day) & 6.70 \\
Ca (g/day) & 67.20 \\
P (g/day) & 4.50 \\
\hline
\end{tabular}

${ }^{\mathrm{a} C o m p o s i t i o n / k i l o g r a m: ~} 19.26 \mathrm{~g}$ of Fe, $4.30 \mathrm{~g}$ of $\mathrm{Cu}, 9.29 \mathrm{~g}$ of $\mathrm{Mn}$, $11.94 \mathrm{~g}$ of $\mathrm{Zn}, 0.08 \mathrm{mg}$ of $\mathrm{Co}, 0.93 \mathrm{mg}$ of $\mathrm{S}, 0.07 \mathrm{mg}$ of Se, $67.11 \mathrm{mg}$ $\mathrm{Na}, 779.18 \mathrm{IU}$ vitamin $\mathrm{A}_{1}, 90.85 \mathrm{IU}$ vitamin $\mathrm{D}_{3}$, and $7.96 \mathrm{IU}$ vitamin $\mathrm{E}$.

${ }^{\mathrm{b}}$ Based on intake at $1 \times$ maintenance. DM, dry matter.

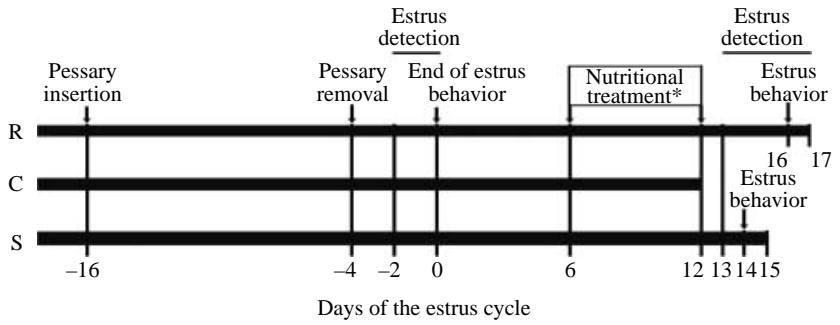

Figure 5 Schematic representation of the experimental design. ${ }^{*} 6$ days nutritional treatment and glucose and metabolic hormone measurements. $\mathrm{R}$ indicates the restricted group; $\mathrm{C}$ indicates the control group; $\mathrm{S}$ indicates the supplemented group.

816-2004; China). The $\mathrm{C}$ group received a maintenance diet (M; 1040 g/ewe per day) while the $\mathrm{S}$ group and $\mathrm{R}$ group received $1.5 \times \mathrm{M}(1560 \mathrm{~g} / \mathrm{ewe}$ per day) diet and $0.5 \times \mathrm{M}$ (520 g/ewe per day) diet respectively. All ewes received two equal allotments of feed at 0900 and $1700 \mathrm{~h}$. Water was available to the ewes ad libitum.

\section{Experimental design}

A schematic representation of the experimental design is shown in Fig. 5. Estrus was synchronized with intravaginal progestogen sponges $(30 \mathrm{mg}$; Pharmp PTY, Melbourne, VIC, Australia) for 12 days. Estrus behavior was detected by testing the ewes with vasectomized rams from the second day of pessary removal $(0800$ and $1600 \mathrm{~h})$. The end of estrus behavior was considered to be day 0 of the estrus cycle. Three groups of ewes were fed different diets for 6 days, from $1600 \mathrm{~h}$ of day 6 to $1600 \mathrm{~h}$ of day 12 of the cycle. They received a maintenance diet on other days of cycle. Some ewes ( $R, n=11 ; C, n=6$; and $S, n=11$ ) were slaughtered on day 12 of the estrous cycle. The remaining ewes, whose estrus behavior was detected from day 13 of the cycle, were slaughtered on the second day of the start of estrus behavior.

\section{Blood collection}

In some ewes whose ovaries were scheduled to be dissected in the luteal phase, blood ( $5 \mathrm{ml}$ ) was sampled $(\mathrm{R}, n=5 ; \mathrm{C}, n=5$; and $S, n=6$ ) from the jugular vein by venipuncture at $0900 \mathrm{~h}$ (always before feeding) and $1600 \mathrm{~h}$ each day, starting at the time of pessary removal. Blood was placed immediately in heparinized tubes, maintained on ice, separated by centrifugation at $4{ }^{\circ} \mathrm{C}$, and stored at $-20^{\circ} \mathrm{C}$ for hormonal measurements. Blood samples ( $2 \mathrm{ml}$; $\mathrm{R}, n=6$; $\mathrm{C}, n=6$; and $\mathrm{S}$, $n=6$ ) for measuring glucose were collected from jugular vein at $0800,0900,1000,1100,1200,1400$, and $1600 \mathrm{~h}$ on days 7 , 8,10 , and 12 of the cycle and placed immediately in tubes containing sodium fluoride and potassium oxalate $(U$ - Real Medical Technology Co., Ltd, Zhejiang, China), separated by centrifugation at $4{ }^{\circ} \mathrm{C}$, and stored at $-20{ }^{\circ} \mathrm{C}$ for analysis.

\section{Collection and dissection of ovaries}

At the end of the experiment, the animals were slaughtered. The procedures for collecting and dissecting ovaries (Carson 
et al. 1981, Boukhliq et al. 1996, Somchit et al. 2007) were used with minor modifications. Briefly, the ovaries were collected within $5 \mathrm{~min}$ of death and placed in ice-cold Dulbecco's PBS (D-PBS; Gibco). The ovaries (36 ovaries) from 18 ewes (six ewes per group) were dissected and CL from each ewe were counted. The remaining ovaries (20 ovaries) from ten ewes in the $\mathrm{R}$ and $\mathrm{S}$ groups were snap-frozen in liquid nitrogen for further analysis and $C L$ from each ewe were counted. All visible follicles $>1.0 \mathrm{~mm}$ in diameter were dissected free from the ovarian stroma using fine scissors and fine-toothed dissecting forceps and placed in PBS (D-PBS) in a sterile plastic Petri dish. Follicular diameter was measured to the nearest millimeter, using a graph paper grid placed under the dish. Each follicle was then hemisected in $1 \mathrm{ml}$ sterile PBS in a 24-well sterile cell culture plate (Nest Biotech Co., Ltd, Wuxi, China). The granulosa cell layer was gently scraped into the D-PBS using a curved eyetweezer. The thecal shell was placed in a $1.5 \mathrm{ml}$ microtube. The D-PBS containing the granulosa cells and follicular fluid was then placed in another $1.5 \mathrm{ml}$ microtube and centrifuged at $4{ }^{\circ} \mathrm{C}$ and $17949 \mathrm{~g}$ (13 000 r.p.m.) for $10 \mathrm{~min}$. Following centrifugation, the supernatant containing diluted follicular fluid was transferred into a $1.5 \mathrm{ml}$ microtube and stored at $-20{ }^{\circ} \mathrm{C}$. The separated thecal shell and the granulosa cell pellet were snap-frozen in liquid nitrogen for further gene expression analysis.

\section{Follicular classification}

Follicles were classified and processed according to their diameter (Viñoles 2003, Somchit et al. 2007) as follows. For follicles $>2.5 \mathrm{~mm}$, follicular fluid from each individual follicle was analyzed. For follicles of $2.0-2.5$ and $<2.0 \mathrm{~mm}$, follicular fluid was analyzed collectively. The volume of follicular fluid (V) was calculated as described (Carson et al. 1981) using the following formula: $V=0.52(D)^{2.7}$, where $V$ is the volume of fluid $\left(\mathrm{mm}^{3}\right)$ and $D$ is the follicle diameter $(\mathrm{mm})$.

Follicles were then grouped into three classes for follicle count analysis: $2.0-2.5,2.5-3.5$, and $\geq 3.5 \mathrm{~mm}$ (Somchit et al. 2007). Follicles for follicular fluid metabolite and hormone analyses were grouped into two classes: $\leq 2.5$ and $>2.5 \mathrm{~mm}$.

\section{Metabolite and hormone assays}

\section{Plasma analyses}

Plasma glucose and hormone were analyzed in samples from day 7 to day 12 .

Glucose concentrations were analyzed by colorimetry using the glucose hexokinase (GOD-PAP) method. Briefly, $10 \mu \mathrm{l}$ plasma was pipetted into duplicate wells on a 96-well plate. A standard curve was also pipetted in triplicate onto each plate. In addition, $1 \mathrm{ml}$ glucose reagent was added to all wells. The plates were read at $505 \mathrm{~nm}$, after which $10 \mu \mathrm{l}$ glucose reagent enzyme was added to all wells and the plates were read a second time at $505 \mathrm{~nm}$. The intra-assay coefficient of variation (CV) was $\leq 3 \%$. The inter-assay $\mathrm{CV}$ was $\leq 5 \%$ and the limit of sensitivity for glucose assay was $0.5 \mathrm{mmol} / \mathrm{l}$.

Insulin concentrations were measured by an equilibrium competitive RIA using a commercial kit (Diagnostic Product,
Beijing North Institute of Biological Technology, Beijing, China). According to the manufacturer, the sensitivity of the assay is $2 \mu \mathrm{lU} / \mathrm{ml}$. The intra-assay CV was $<10 \%$ and the interassay $\mathrm{CV}$ was $<15 \%$.

Glucagon concentrations were measured by a non-equilibrium competitive RIA using commercial kit (Diagnostic Product, Beijing North Institute of Biological Technology). According to the manufacturer, the sensitivity of the assay is $16.1 \mathrm{pg} / \mathrm{ml}$. The intra-assay CV was $<10 \%$ and the inter-assay CV was $<15 \%$.

\section{Follicular fluid analyses}

Glucose concentrations were determined in all follicle samples, in $60 \mu \mathrm{l}$, by colorimetry using the glucose oxidase method (Nanjing Jiancheng Bioengineering Institute, Nanjing, China). $\mathrm{LDH}$ and urea were measured in all follicle samples using the lactate and the UV-GLDH methods respectively (Diagnostic kit; Shanghai Kehua Bio-engineering Co., Ltd, Shanghai, China) on a clinical chemistry analyzer (Selectra E; Vital Scientific N.V., Dieren, The Netherlands) according to the manufacturer's instructions. The intra-assay CV was $\leq 5 \%$.

Insulin was analyzed by a saturated equilibrium competitive RIA in all follicular fluid samples using commercial kit (Beijing Furui Bio-Tech Co. Ltd, Beijing, China). According to the manufacturer, the sensitivity of the assay is $<1.5 \mu \mathrm{lU} / \mathrm{ml}$. The intra-assay $\mathrm{CV}$ was $<10 \%$ and the inter-assay $\mathrm{CV}$ was $<15 \%$.

Glucagon was analyzed in all follicular fluid samples by a non-equilibrium competitive RIA using commercial kit (Diagnostic Product, Beijing North Institute of Biological Technology) as described above.

$\mathrm{E}_{2}$, progesterone, and testosterone were analyzed in all follicular fluid samples by an equilibrium competitive RIA using commercial kit (Beijing Furui Bio-Tech Co. Ltd). According to the manufacturer, the sensitivity of the assays is $0.5 \mathrm{pg} / \mathrm{ml}, 0.02 \mathrm{ng} / \mathrm{ml}$, and $2.08 \mathrm{pg} / \mathrm{ml}$. The intra-assay CV are all $<10 \%$ and the inter-assay $\mathrm{CV}$ are all $<15 \%$.

\section{Gene expression analysis}

To strengthen the endocrine data, mRNA expression of steroidogenic genes CYP19A1, STAR, and CYP11A1 was analyzed using real-time quantitative PCR. For each ewe, the collected granulosa cells and thecal shell samples from each follicle size class were mixed. Total RNA was isolated from a group of follicles $1.0-2.0$ and $2.0-2.5 \mathrm{~mm}$ and individual follicles $>2.5 \mathrm{~mm}$ using a High Pure RNA Tissue Kit (Roche), which included DNase I digestion. RNA was reverse transcribed using PrimeScriptR RT Master Mix according to the manufacturer's protocol (TakaRa Biotechnology Co. Ltd, Dalian, China). The specific primers used for detection of ovine CYP19A1 and STAR transcripts have been described previously (Drouilhet et al. 2010); the specific primers for detection of ovine $\beta$-actin and CYP11A1 were designed using Primer Premier Software 5 (Premier Biosoft International, Palo Alto, CA, USA). The qPCR primer sequences used are as follows: $\beta$-actin (144 bp; F: $5^{\prime}$-GCAGTTGTGGATCAGCAAGC$3^{\prime}$ and R: 5'-GGGCAATCTCATCTCGTTTTC- $3^{\prime}$ ) and CYP11A1 (158 bp; F: 5'-GTTTCGCTTTGCCTTTGAGTC-3' and R: 5'-ACAGTTCTGGAGGGAGGTTGA-3'). 
Real-time PCR assessment was performed in an ABI 7300 Sequence Detection System (Applied Biosystems, Foster City, CA, USA) programmed to conduct 40 cycles $\left(95^{\circ} \mathrm{C}\right.$ for $15 \mathrm{~s}$, $60{ }^{\circ} \mathrm{C}$ for $30 \mathrm{~s}$ and $72{ }^{\circ} \mathrm{C}$ for $30 \mathrm{~s}$ ). Each sample was assayed in triple using the equivalent of $1 \mu \mathrm{l}$ CDNA, $0.6 \mu \mathrm{l}(10 \mathrm{mM})$ of each primer, and $10 \mu \mathrm{l}$ FastStart Universal SYBR Green Master (ROX; Roche) in a total reaction volume of $20 \mu \mathrm{l}$. For each primer pair, efficiency curves were generated using serial dilutions of cDNA in the abscissa and the corresponding cycle threshold $\left(C_{\mathrm{t}}\right)$ in the ordinate. Quantitative differences in the target gene were determined according to the ratio

$R=\left[E_{\beta \text {-actin }}^{C_{\text {B-actin }}} / E_{\text {target }}^{C_{\mathrm{t} \text { target }}}\right]$,

where amplification efficiency $(E)$ was calculated from the formula $E=\mathrm{e}(-1 /$ slope) (Drouilhet et al. 2010). The efficiency of PCR for the CYP19A1, STAR, $\beta$-actin, and CYP11A1 genes was $1.96,1.85,1.94$, and 1.95 respectively.

\section{Statistical analysis}

The concentrations of hormones and metabolites in follicular fluid are based on a dilution factor calculated from the theoretical volume of the follicle volume added to $1 \mathrm{ml}$ PBS.

Statistical analyses were performed using the SPSS statistical software program (version 13.0; SPSS Inc., Chicago, IL, USA). The data are presented as mean \pm S.E.M. and the differences are regarded as significant at $P<0.05$. The distribution of all data was first confirmed for their agreement with normal distribution using the Kolmogorov-Smirnov goodness-of-fit test. Where data were not normally distributed, they were log-transformed, re-tested for normality before analysis, and, if still not normalized, the data were tested using the equivalent nonparametric test. Statistical analyses were carried out as follows: 1) for the analysis of repeated measurements, the linear mixed model of SPSS was used with comparisons using the Bonferroni correction. The model included the fixed effects of treatment and day and their interaction. Data with repeated measurements included body weight, body condition, and hormone and metabolite concentrations in plasma. 2) For follicles $\leq 2.5$ or $>2.5 \mathrm{~mm}$ in diameter, data were analyzed for treatment effect using one-way ANOVA. Post-hoc differences between treatment groups were further examined using Tukey's test. 3) For each treatment group, data on follicles $\leq 2.5$ and $>2.5 \mathrm{~mm}$ in diameter were analyzed using independent samples T-test. 4) Two-way ANOVA with follicle size as one variable and nutrient as the other variable was carried out to study the follicle size and nutritional treatment effects. 5) Stepwise multiple linear regression analysis was performed to determine the factors that were associated significantly with variations in the follicular diameter. 6) Follicle counts and follicle distributions were tested by the $\chi^{2}$ test using Fisher's exact probability test.

\section{Declaration of interest}

The authors declare that there is no conflict of interest that could be perceived as prejudicing the impartiality of the research reported.

\section{Funding}

This work was supported by National Industrial Technology System of Sheep and Goat (grant number nycytx-39); the Open Fund of Jiangsu Province for Laboratory of Animal Genetics, Breeding and Reproduction (grant number YDKT0801).

\section{Acknowledgements}

The authors wish to thank Li Meng and Hui Song for their excellent work and Xunsheng Pang and Guomin Zhang for their help in the collection of the experimental materials.

\section{References}

Alexander BM, Kiyma Z, McFarland M, Van Kirk EA, Hallford DM, Hawkins DE, Kane KK \& Moss GE 2007 Influence of short-term fasting during the luteal phase of the estrous cycle on ovarian follicular development during the ensuing proestrus of ewes. Animal Reproduction Science 97 356-363. (doi:10.1016/j.anireprosci.2006.01.012)

Avery B, Strobech L, Jacobsen T, Bogh IB \& Greve T 2003 In vitro maturation of bovine cumulus-oocyte complexes in undiluted follicular fluid: effect on nuclear maturation, pronucleus formation and embryo development. Theriogenology 59 987-999. (doi:10.1016/S0093-691X (02)01139-1)

van Barneveld RJ 1999 Understanding the nutritional chemistry of lupin (Lupinus spp.) seed to improve livestock production efficiency. Nutrition Research Reviews 12 203-230. (doi:10.1079/095442299108728938)

Bobe G, Ametaj BN, Young JW, Anderson LL \& Beitz DC 2007 Exogenous glucagon effects on health and reproductive performance of lactating dairy cows with mild fatty liver. Animal Reproduction Science 102 194-207. (doi:10.1016/j.anireprosci.2006.11.003)

Boukhliq R, Adams NR \& Martin GB 1996 Effect of nutrition on the balance of production of ovarian and pituitary hormones in ewes. Animal Reproduction Science 45 59-70. (doi:10.1016/S0378-4320(96)01552-7)

Brand A \& de Jong WH 1973 Qualitative and quantitative micromorphological investigations of the tertiary follicle population during the oestrous cycle in sheep. Journal of Reproduction and Fertility 33 431-439. (doi:10.1530/jrf.0.0330431)

Campbell BK, Scaramuzzi RJ \& Webb R 1996 Induction and maintenance of oestradiol and immunoreactive inhibin production with FSH by ovine granulosa cells cultured in serum-free media. Journal of Reproduction and Fertility 106 7-16. (doi:10.1530/jrf.0.1060007)

Carson RS, Findlay JK, Clarke IJ \& Burger HG 1981 Estradiol, testosterone, and androstenedione in ovine follicular fluid during growth and atresia of ovarian follicles. Biology of Reproduction 24 105-113. (doi:10.1095/ biolreprod24.1.105)

Cascieri MA, Koch GE, Ber E, Sadowski SJ, Louizides D, de Laszlo SE, Hacker C, Hagmann WK, MacCoss M, Chicchi GG et al. 1999 Characterization of a novel, non-peptidyl antagonist of the human glucagon receptor. Journal of Biological Chemistry 274 8694-8697. (doi:10.1074/jbc.274.13.8694)

Chang SC, Jones JD, Ellefson RD \& Ryan RJ 1976 The porcine ovarian follicle: I. Selected chemical analysis of follicular fluid at different developmental stages. Biology of Reproduction 15 321-328. (doi:10. 1095/biolreprod15.3.321)

Chun SY, Eisenhauer KM, Minami S, Billig H, Perlas E \& Hsueh AJ 1996 Hormonal regulation of apoptosis in early antral follicles: folliclestimulating hormone as a major survival factor. Endocrinology 137 1447-1456. (doi:10.1210/en.137.4.1447)

Downing JA \& Scaramuzzi RJ 1991 Nutrient effects on ovulation rate, ovarian function and the secretion of gonadotrophic and metabolic hormones in sheep. Journal of Reproduction and Fertility Supplement 43 209-227.

Downing JA \& Scaramuzzi RJ 1995 The effect of the infusion of insulin during the luteal phase of the estrous cycle on the ovulation rate and on plasma concentrations of $\mathrm{LH}, \mathrm{FSH}$ and glucose in ewes. Theriogenology 47 747-759. (doi:10.1016/S0093-691X(97)00031-9) 
Downing JA, Joss J, Connell P \& Scaramuzzi RJ 1995a Ovulation rate and the concentrations of gonadotrophic and metabolic hormones in ewes fed lupin grain. Journal of Reproduction and Fertility 103 137-145. (doi:10.1530/jrf.0.1030137)

Downing JA, Joss J \& Scaramuzzi RJ 1995b A mixture of the branched chain amino acids leucine, isoleucine and valine increases ovulation rate in ewes when infused during the late luteal phase of the oestrous cycle: an effect that may be mediated by insulin. Journal of Endocrinology 145 315-323. (doi:10.1677/joe.0.1450315)

Downing JA, Joss J \& Scaramuzzi RJ 1995 c Ovulation rate and the concentrations of gonadotrophins and metabolic hormones in ewes infused with glucose during the late luteal phase of the oestrous cycle. Journal of Endocrinology 146 403-410. (doi:10.1677/joe.0.1460403)

Downing JA, Joss J \& Scaramuzzi RJ 1999 The effect of a direct arterial infusion of insulin and glucose on the ovarian secretion rates of androstenedione and oestradiol in ewes with an autotransplanted ovary. Journal of Endocrinology 163 531-541. (doi:10.1677/joe.0. 1630531)

Drouilhet L, Taragnat C, Fontaine J, Duittoz A, Mulsant P, Bodin L \& Fabre S 2010 Endocrine characterization of the reproductive axis in highly prolific lacaune sheep homozygous for the FecLL mutation. Biology of Reproduction 82 815-824. (doi:10.1095/biolreprod.109.082065)

Fortune JE, Rivera GM \& Yang MY 2004 Follicular development: the role of the follicular microenvironment in selection of the dominant follicle. Animal Reproduction Science 82-83 109-126. (doi:10.1016/j.anireprosci.2004.04.031)

Franke RP, Fuhrmann R, Mrowietz C, Rickert D, Hiebl B \& Jung F 2010 Reduced diagnostic value of lactate dehydrogenase (LDH) in the presence of radiographic contrast media. Clinical Hemorheology and Microcirculation 45 123-130. (doi:10.3233/CH-2010-1290)

Gull I, Geva E, Lerner-Geva L, Lessing JB, Wolman I \& Amit A 1999 Anaerobic glycolysis. The metabolism of the preovulatory human oocyte. European Journal of Obstetrics, Gynecology, and Reproductive Biology 85 225-228. (doi:10.1016/S0301-2115(99)00012-3)

Hansen LH, Abrahamsen N \& Nishimura E 1995 Glucagon receptor mRNA distribution in rat tissues. Peptides 16 1163-1166. (doi:10.1016/01969781(95)00078-X)

Harris SE, Gopichandran N, Picton HM, Leese HJ \& Orsi NM 2005 Nutrient concentrations in murine follicular fluid and the female reproductive tract. Theriogenology 64 992-1006. (doi:10.1016/j.theriogenology. 2005.01.004)

Heurich RO, Buggy JJ, Vandenberg MT \& Rossomando AJ 1996 Glucagon induces a rapid and sustained phosphorylation of the human glucagon receptor in Chinese hamster ovary cells. Biochemical and Biophysical Research Communications 220 905-910. (doi:10.1006/bbrc. 1996.0504)

Kaipia A \& Hsueh AJ 1997 Regulation of ovarian follicle atresia. Annual Review of Physiology 59 349-363. (doi:10.1146/annurev.physiol. 59.1.349)

Landau S, Braw-Tal R, Kaim M, Bor A \& Bruckental I 2000 Preovulatory follicular status and diet affect the insulin and glucose content of follicles in high-yielding dairy cows. Animal Reproduction Science 64 181-197. (doi:10.1016/S0378-4320(00)00212-8)

Matsuda-Minehata F, Inoue N, Goto Y \& Manabe N 2006 The regulation of ovarian granulosa cell death by pro- and anti-apoptotic molecules. Journal of Reproduction and Development 52 695-705. (doi:10.1262/ jrd.18069)

Moor RM, Hay MF, Dott HM \& Cran DG 1978 Macroscopic identification and steroidogenic function of atretic follicles in sheep. Journal of Endocrinology 77 309-318. (doi:10.1677/joe.0.0770309)

Munoz-Gutierrez M, Blache D, Martin GB \& Scaramuzzi RJ 2002 Folliculogenesis and ovarian expression of mRNA encoding aromatase in anoestrous sheep after 5 days of glucose or glucosamine infusion or supplementary lupin feeding. Reproduction 124 721-731. (doi:10.1530/ rep.0.1240721)

Munoz-Gutierrez M, Blache D, Martin GB \& Scaramuzzi RJ 2004 Ovarian follicular expression of mRNA encoding the type I IGF receptor and IGFbinding protein-2 in sheep following five days of nutritional supplementation with glucose, glucosamine or lupins. Reproduction $\mathbf{1 2 8}$ 747-756. (doi:10.1530/rep.1.00439)

Munoz-Gutierrez M, Findlay PA, Adam CL, Wax G, Campbell BK, Kendall NR, Khalid M, Forsberg M \& Scaramuzzi RJ 2005 The ovarian expression of mRNAs for aromatase, IGF-I receptor, IGF-binding protein-2, -4 and -5 , leptin and leptin receptor in cycling ewes after three days of leptin infusion. Reproduction 130 869-881. (doi:10.1530/ rep.1.00557)

Nandi S, Kumar VG, Manjunatha BM \& Gupta PS 2007 Biochemical composition of ovine follicular fluid in relation to follicle size. Development, Growth \& Differentiation 49 61-66. (doi:10.1111/j. 1440-169X.2007.00901.x)

Nottle MB, Armstrong DT, Setchell BP \& Seamark RF 1985 Lupin feeding and folliculogenesis in the Merino ewe. Proceedings of the Nutrition Society of Australia 10145.

Rhind SM \& McNeilly AS 1986 Follicle populations, ovulation rates and plasma profiles of LH, FSH and prolactin in Scottish Blackface ewes in high and low levels of body condition. Animal Reproduction Science 10 105-115. (doi:10.1016/0378-4320(86)90022-9)

Rhind SM, McMillen S, McKelvey WA, Rodriguez-Herrejon FF \& McNeilly AS 1989 Effect of the body condition of ewes on the secretion of $\mathrm{LH}$ and $\mathrm{FSH}$ and the pituitary response to gonadotrophin-releasing hormone. Journal of Endocrinology 120 497-502. (doi:10.1677/joe.0. 1200497)

Richards MW, Wettemann RP \& Schoenemann HM 1989 Nutritional anestrus in beef cows: body weight change, body condition, luteinizing hormone in serum and ovarian activity. Journal of Animal Science $\mathbf{6 7}$ 1520-1526.

Rosenfeld CS, Wagner JS, Roberts RM \& Lubahn DB 2001 Intraovarian actions of oestrogen. Reproduction 122 215-226. (doi:10.1530/rep.0. 1220215)

Russel AJF, Doney JM \& Gunn RG 1969 Subjective assessment of body fat in live sheep. Journal of Agricultural Science 72 451-454. (doi:10.1017/ S0021859600024874)

Scaramuzzi RJ, Adams NR, Baird DT, Campbell BK, Downing JA, Findlay JK, Henderson KM, Martin GB, McNatty KP, McNeilly AS et al. $1993 \mathrm{~A}$ model for follicle selection and the determination of ovulation rate in the ewe. Reproduction, Fertility, and Development $\mathbf{5}$ 459-478. (doi:10.1071/RD9930459)

Scaramuzzi RJ, Campbell BK, Downing JA, Kendall NR, Khalid M, MunozGutierrez M \& Somchit A 2006 A review of the effects of supplementary nutrition in the ewe on the concentrations of reproductive and metabolic hormones and the mechanisms that regulate folliculogenesis and ovulation rate. Reproduction, Nutrition, Development 46 339-354. (doi:10.1051/rnd:2006016)

Scaramuzzi RJ, Brown HM \& Dupont J 2010 Nutritional and metabolic mechanisms in the ovary and their role in mediating the effects of diet on folliculogenesis: a perspective. Reproduction in Domestic Animals 45 (Supplement 3) 32-41. (doi:10.1111/j.14390531.2010.01662.x)

Somchit A, Campbell BK, Khalid M, Kendall NR \& Scaramuzzi RJ 2007 The effect of short-term nutritional supplementation of ewes with lupin grain (Lupinus luteus), during the luteal phase of the estrous cycle on the number of ovarian follicles and the concentrations of hormones and glucose in plasma and follicular fluid. Theriogenology 68 1037-1046. (doi:10.1016/j.theriogenology.2007.08.001)

Sutton-McDowall ML, Gilchrist RB \& Thompson JG 2010 The pivotal role of glucose metabolism in determining oocyte developmental competence. Reproduction 139 685-695. (doi:10.1530/REP-09-0345)

Tanaka T, Fujiwara K, Kim S, Kamomae H \& Kaneda Y 2004 Ovarian and hormonal responses to a progesterone-releasing controlled internal drug releasing treatment in dietary-restricted goats. Animal Reproduction Science 84 135-146. (doi:10.1016/j.anireprosci.2003.12.007)

Teleni E, Rowe JB, Croker KP, Murray PJ \& King WR 1989 Lupins and energy-yielding nutrients in ewes. II. Responses in ovulation rate in ewes to increased availability of glucose, acetate and amino acids. Reproduction, Fertility, and Development 1 117-125. (doi:10.1071/ RD9890117)

Turnbull KE, Braden AW \& Mattner PE 1977 The pattern of follicular growth and atresia in the ovine ovary. Australian Journal of Biological Science $\mathbf{3 0}$ 229-241.

Viñoles C 2003 Effect of nutrition on follicle development and ovulation rate in ewe. PhD Thesis. Swedish University of Agricultural Sciences.

Viñoles C, Forsberg M, Banchero G \& Rubianes E 2002 Ovarian follicular dynamics and endocrine profiles in Polwarth ewes with high and low body condition. Animal Science 74 535-545. 
Viñoles C, Forsberg M, Martin GB, Cajarville C, Repetto J \& Meikle A 2005 Short-term nutritional supplementation of ewes in low body condition affects follicle development due to an increase in glucose and metabolic hormones. Reproduction 129 299-309. (doi:10.1530/rep.1.00536)

Wang J, Wang Y, Li X, Li J \& Leung FC 2008 Cloning, tissue distribution, and functional characterization of chicken glucagon receptor. Poultry Science 87 2678-2688. (doi:10.3382/ps.2008-00260)

Webb R, Campbell BK, Garverick HA, Gong JG, Gutierrez CG \& Armstrong DG 1999 Molecular mechanisms regulating follicular recruitment and selection. Journal of Reproduction and Fertility Supplement 54 33-48.

Williams SA, Blache D, Martin GB, Foot R, Blackberry MA \& Scaramuzzi RJ 2001 Effect of nutritional supplementation on quantities of glucose transporters 1 and 4 in sheep granulosa and theca cells. Reproduction 122 947-956. (doi:10.1530/rep.0.1220947)

Wise T 1987 Biochemical analysis of bovine follicular fluid: albumin, total protein, lysosomal enzymes, ions, steroids and ascorbic acid content in relation to follicular size, rank, atresia classification and day of estrous cycle. Journal of Animal Science 64 1153-1169.
Yen HW, Jakimiuk AJ, Munir I \& Magoffin DA 2004 Selective alterations in insulin receptor substrates-1, -2 and -4 in theca but not granulosa cells from polycystic ovaries. Molecular Human Reproduction 10 473-479. (doi:10.1093/molehr/gah066)

Yu YS, Sui HS, Han ZB, Li W, Luo MJ \& Tan JH 2004 Apoptosis in granulosa cells during follicular atresia: relationship with steroids and insulin-like growth factors. Cell Research 14 341-346. (doi:10.1038/sj. cr.7290234)

Zhengzhong X, McDonald MF \& McCucheon SN 1989 The effects of nutritionally-induced liveweight differences on follicular development, ovulation rate, oestrous activity and plasma follicle-stimulating hormone levels in the ewe. Animal Reproduction Science 19 67-78. (doi:10.1016/ 0378-4320(89)90047-X)

Received 27 June 2011

First decision 1 August 2011

Accepted 5 September 2011 